\title{
Anti-inflammatory potential of dichloromethane leaf extracts of Eucalyptus globulus (Labill) and Senna didymobotrya (Fresenius) in mice
}

\author{
Joseph Kiambi Mworia ${ }^{1}$, Cromwell Mwiti Kibiti², Joseph JN Ngeranwa ${ }^{1}$, Mathew Piero Ngugi ${ }^{1}$
}

1. Department of Biochemistry, Microbiology and Biotechnology, Kenyatta University, P.O Box 43844-00100, Nairobi, Kenya.

2. Department of Pure and Applied Sciences, Technical University of Mombasa, P.O Box 90420-80100, Mombasa, Kenya.

\begin{abstract}
Author details:
Cromwell Mwiti Kibiti: Email: cromwellkibiti@tum.ac.ke: Phone number: +254791427415;

orcid/0000-0002-3611-4427; Joseph JN Ngeranwa: Email: ngeranwa.joseph@ku.ac.ke:

Phone number: +254722268093; orcid /0000-0002-1158-5521; Mathew Piero Ngugi: Email:

piero.mathew@ku.ac.ke: Phone number: +254710349485/+254 732264557; orcid /0000-0002-0226-9092.
\end{abstract}

\begin{abstract}
Background: Inflammation is an immune response characterized by swelling, redness, pain and heat. Inflammation is mainly managed using conventional medicines that are associated with many side effects. Plant-based remedies are considerably better alternative therapies for they have fewer side effects.

Objective: This study aimed at determining the anti-inflammatory potential of dichloromethane (DCM) leaf extracts of Eucalyptus globulus and Senna didymobotrya in mice.

Methods: Fresh leaves of these plants were harvested from Embu County, Kenya. Quantitative phytochemical analysis was done using Gas Chromatography-Mass Spectrometry (GC-MS). Anti-inflammatory test comprised nine groups of five animals each: normal, negative, positive controls and 6 experimental groups. Inflammation was induced with Carrageenan. One hour post-treatment, the different groups were intraperitoneally administered with the reference drug, diclofenac, $3 \%$ DMSO and six DCM leaf extracts at doses of 25, 50, 100, 150, 200 and $250 \mathrm{mg} / \mathrm{kgbw}$.

Results: GC-MS results revealed $\alpha$-phellandrene, camphene, terpinolene, and limonene among others. Anti-inflammatory effects showed that extract doses of 100,150,200 and $250 \mathrm{mg} / \mathrm{kg}$ bw significantly reduced the inflamed paw. Doses of 200 and $250 \mathrm{mg} / \mathrm{kgbw}$ in both plants were more potent and compared with diclofenac. E. globulus extract dose of $250 \mathrm{mg} \mathrm{kg} b \mathrm{bw}$ reduced inflamed paw in the $1^{\text {st }}, 2^{\text {nd }}, 3^{\text {rd }}$ and $4^{\text {th }}$ hours, by $2.27,6.52,9.09$ and $10.90 \%$ respectively while $S$.didymobotrya at similar dose ranges, inflamed paw reduced by $2.41,5.43,8.31$ and $9.05 \%$ respectively.

Conclusion: E. globulus and $S$. didymobotrya have potent anti-inflammatory activities, attributed to their constituent phytochemicals. This study confirms the traditional use of these plants in treating inflammation.
\end{abstract}

Keywords: Eucalyptus globulus, Senna didymobtrya, inflammation, phytochemicals.

DOI: https://dx.doi.org/10.4314/ahs.v21i1.50

Cite as: Mworia JK, Kibiti CM, Ngeranwa JJN, Ngugi MP. Anti-inflammatory potential of dichloromethane leaf extracts of Eucalyptus globulus (Labill) and Senna didymobotrya (Fresenius) in mice. Afri Health Sci. 2021;21(1):397-409. bttps:/ / dx.doi.org/10.4314/abs.v21i1.50

\section{Introduction}

Inflammation is a complex biological reaction of the vascular tissues to noxious stimuli like damaged cells,

\section{Corresponding author: \\ Joseph Kiambi Mworia, \\ Department of Biochemistry, Microbiology \\ and Biotechnology, Kenyatta University, \\ P.O Box 43844-00100, Nairobi, Kenya. \\ Phone number: +254724420320 \\ Email: kiambijoseph2013@gmail.com}

irritants and pathogens ${ }^{1}$. The objective of the inflammatory response is to limit and remove the causative agents of inflammation as well as to initiate the healing process in the damaged cells ${ }^{2}$. Inflammation is mainly managed using NSAIDs such as Ibuprofen, Naproxen Sodium and Diclofenac among others ${ }^{3}$. These drugs are associated with numerous side effects in the gastrointestinal tract, kidney, liver, cardiovascular system among others ${ }^{4}$. Inflammation is also managed using medicinal plants such as Azima tetracantha (Lam) ${ }^{5}$, Eugenia jambola$n a^{6}$ among others. Herbal medicines serve as better al- 
ternatives for they are arguably readily available, cheap and possess fewer side effects hence the need to search for new bioactive compounds in medicinal plants ${ }^{7}$. E. globulus is an evergreen tree with a straight trunk of about 0.6 to 2 meters in diameter and a height of 40 70 meters tall. It has well spread deep roots along with smooth, brownish, greenish, mottled gray and long peeling bark. Most of them grow naturally in many parts of Kenya ${ }^{8}$. E. globulus is used in the management of abscess, asthma, burns, sore throat, bronchitis, colds, among others'. S. didymobotrya was introduced as an ornamental plant and grow in almost every part of Kenya. It is a bushy shrub found at altitudes of between 14502400 meters above the sea level. The plant grows to a maximum height of about $30-90 \mathrm{~cm}^{10}$. It is used in the management of fungal, bacterial, parasitic infections, hypertension among others ${ }^{11}$. In Embu County, Kenya, E. globulus and S. didymobotrya are used in the traditional medicine in treatment of inflammation. However, there is no scientific data to confirm and/or validate this use. This study sought to explore the anti-inflammatory potential of dichloromethane leaf extracts of E. globulus (Labill) and S. didymobotrya (Fresenius) in mice models.

\section{Materials and methods}

Plant samples harvesting, processing, and extraction.

The researchers obtained research authorization to undertake this study from National Commission for Science, Technology and Innovation, Kenya (NACOSTI/P/16/6765/1452). The collection of the plant samples was carried out based on ethnobotanical information availed by a local herbalist in Mbeere North Subcounty, Embu County,Kenya. Fresh leaves of E. globulus (Labill) and S. didymobotrya (Fresenius) were collected at GPS location of 0o35'12.'S, 37o38'32'E and 0o35'28."S, 37o38'25"E respectively. The samples were cleaned, enveloped in Khaki bags and carried to Kenyatta University in the Department of Biochemistry, Microbiology and Biotechnology, where the study was undertaken. The samples were identified by Mr. Stephen Mwangi, a taxonomist in Kenyatta University. Voucher specimens of E. globulus (Labill) and S. didymobotrya (Fresenius) were deposited at the Plant Sciences Herbarium of Kenyatta University and were assigned voucher specimen numbers JKM001 and JKM002, respectively.
The samples were air-dried at $25^{\circ} \mathrm{C}$ in the plant drying facility of Kenyatta University for 14 days. The dried samples were then milled separately into fine powders using an electric mill. The powders were stored at room temperature in well-sealed and labeled khaki papers awaiting extraction ${ }^{12}$.

For extraction, six hundred grams of each plant powder were separately weighed and put into well-labeled conical flasks. Two liters of dichloromethane were added into each conical flask, corked and left to stand for 24 hours with regular swirling every 6 hours. The mixtures were then decanted in clean and well labeled conical flasks. Filtration was then done using Whatman No.1 filter papers. Each filtrate was put in a well-labeled conical flask. One liter of dichloromethane was added to each residue and then left to stand for 24 hours, followed by decantation and filtration. This procedure was repeated until dichloromethane remained clear. Each extract was concentrated using a rotary evaporator at $40^{\circ} \mathrm{C}$ until dry. The semi-solid extract was separately put in an open clean beaker for 5 days to evaporate the remaining solvent. A sticky solid was obtained and store stored at $-4^{\circ} \mathrm{C}$ until use ${ }^{13}$.

\section{GC-MS analysis}

Quantitative phytochemical analysis of the extract was done at the International Centre of Insect Physiology and Ecology (ICIPE) laboratories. A protocol reviewed by the Principal Scientist and Head of the Department of Behavioral and Chemical Ecology at ICIPE, Prof. Baldwyn Torto, was used to analyze the two plant extracts. The DCM extracts of E. globulus (Labill) and $S$. didymobotrya (Fresenius) DCM weighing 1.1 and $1.2 \mathrm{mg}$ respectively were diluted in their respective volumes through partitionng between hexane and methanol. This was followed by vortexes and centrifugation. Bypassing through anhydrous $\mathrm{Na}_{2} \mathrm{SO}_{4}$, the hexane layer was dried and then analyzed using GC-MS. Standard authentic serial dilutions (1,8-cineole; 99\%,Gillingham,Dorset, England) (50ng/ $\mu \mathrm{l}, 150 \mathrm{ng} / \mu \mathrm{l}, 250 \mathrm{ng} / \mu \mathrm{l}, 350$ $\mathrm{ng} / \mu \mathrm{l}$ and $550 \mathrm{ng} / \mu \mathrm{l})$ were prepared, analyzed using GC-MS and their peaks used in quantification. The calibration curve of 1,8-cineole (peak area vs. concentration), with the equation $y=7 \mathrm{E}+06-1 \mathrm{E}+07$, served as the basis for the external quantification of the target compounds Figure 1. 


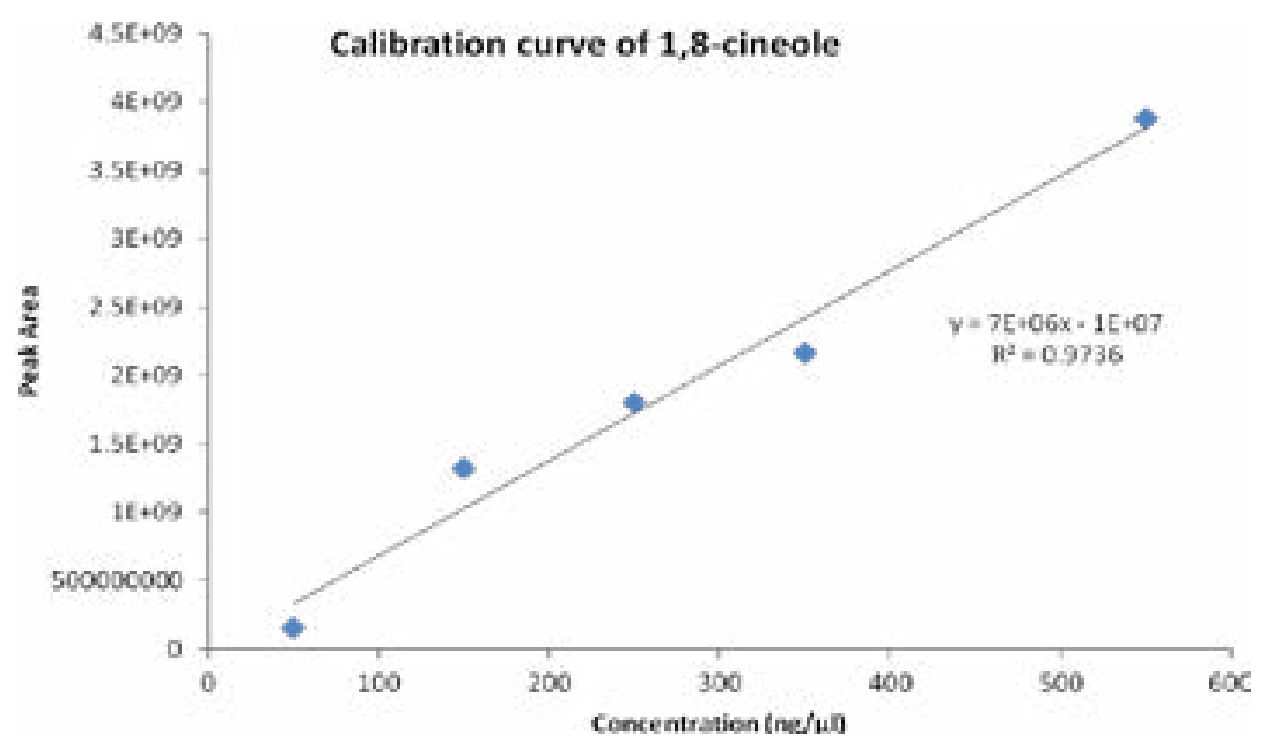

Figure 1: The calibration curve of 1,8-cineole (peak area vs. concentration)

Agilent Gas Chromatograph 7890A/5975C coupled to Mass Spectrometer in full scan mode was used to analyze the two plant extracts using the following specifications; gas chromatography Column (HP-5 MS low bleed capillary column $(0.25 \mu \mathrm{m}, 30 \mathrm{~m}$ by $0.25 \mathrm{~mm}$ i.d. $)$ (J and W, Folsom, California, United States of America), flow rate, (Helium) (constant flow mode at $1.25 \mathrm{ml} /$ min), injection split mode, the temperature of the oven $\left(35^{\circ} \mathrm{C}\right)$ for initial 5 minutes and then raised by $10^{\circ} \mathrm{C}$ per minute to $280^{\circ} \mathrm{C}$ for 10.5 minutes; run time 70 minutes ${ }^{14}$. The percentage abundance of each phytochemical identified by GC-MS was computed using the formula below;

\section{Experimental animals}

Swiss albino mice weighing between 20 to 25 grams and aged 5-6 weeks were used in the present study. They were obtained from Kenyatta University Animal Breeding Facility. The mice were provided with laboratory diet, which comprised rodent pellets and water ad libitum. The mice were housed in groups of nine in standard polypropylene cages and maintained at room temperature $\left(23 \pm 2^{\circ} \mathrm{C}\right)$, bench level lighting of 360 lux and humidity ( $55 \pm 5 \%$ ) with $12 \mathrm{hrs}$ light and $12 \mathrm{hrs}$ dark cycle. Approval for use of laboratory animals in this study was obtained from the Ethics Committee for the Care and Use of Laboratory Animals of Kenyatta University, Kenya (KU/AERC/107-012/2017). Development of the experimental protocols and procedures were performed under the guidance of the Veterinarian, who is a member of the Kenya Veterinary Board
(KVB). All procedures were carried out following the Public Health Service (PHS) Policy on Humane Care and Use Committee (IACUC) (Section 8.3.2) and KVB.

\section{Induction of inflammation}

To induce inflammation, each mouse was injected with $0.1 \mathrm{ml}$ of $1 \%$ Carrageenan (commercial grade type 1) solution in normal saline in the left hind paw. Induction of inflammation was indicated by the manifestation of edema on the hind paw ${ }^{15}$.

\section{Experimental design}

A completely randomized controlled study design was adopted in this study from which an experimental design was derived. Swiss albino mice were categorized into 9 sets of 5 mice each. The animals received treatments as follows; Group I (normal control) mice received 3\% DMSO only and were not induced with inflammation ${ }^{16}$. Group II (negative control) mice were induced with inflammation and administered with $3 \%$ DMSO after one hour ${ }^{17}$. Group III (positive control) animals were induced with inflammation and then treated with the reference drug diclofenac sodium at a dose of $15 \mathrm{mg} / \mathrm{kg}$ body weight after one hour ${ }^{18}$. Animals in groups (IV, V, VI, VII, VIII, and IX) were induced with inflammation and then treated with extracts dosages of $25,50,100,150,200$ and $250 \mathrm{mg} / \mathrm{kg}$ bw respectively after one hour. All the treatment doses were freshly prepared. The summary of this design is detailed in Table 1. The paw circumference (edema) was determined one hour post induction of inflammation and at hourly in- 
tervals after administration of different treatments for four hours. The paw circumference was measured using cotton thread and then transferred to the ruler to obtain the reading in millimeters ${ }^{19}$. The percentage edema inhibition was computed using the formula described by Umamageswari and Kudagi (2015) ${ }^{20}$.

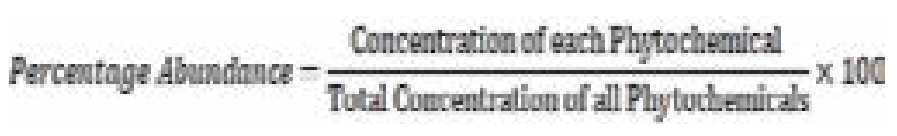

Where, Vc is the Mean edema volume in the control group and $\mathrm{Vt}$ is the Mean edema volume in the treated group.

Table: 1 Summary of experimental design for determination of anti-inflammatory activities of dichloromethane leaf extracts of Eucalyptus globulus (Labill) and Senna didymobotrya (Fresenius) extracts on carrageenan-induced edema in Swiss albino mice.

\begin{tabular}{ll}
\hline Group & Treatment \\
\hline I & DMSO only \\
II & Carrageenan + DMSO \\
III & Carrageenan + diclofenac $(15 \mathrm{mg} / \mathrm{kg}$ body weight $)$ \\
IV & Carrageenan + extract $(25 \mathrm{mg} / \mathrm{kg}$ body weight $)$ \\
V & Carrageenan + extract $(50 \mathrm{mg} / \mathrm{kg}$ body weight $)$ \\
VI & Carrageenan + extract $(100 \mathrm{mg} / \mathrm{kg}$ body weight $)$ \\
VII & Carrageenan + extract $(150 \mathrm{mg} / \mathrm{kg}$ body weight $)$ \\
VIII & Carrageenan + extract $(200 \mathrm{mg} / \mathrm{kg}$ body weight $)$ \\
IX & Carrageenan + extract $(250 \mathrm{mg} / \mathrm{kg}$ body weight $)$ \\
\hline
\end{tabular}

DMSO = Dimethyl sulphoxide

\section{Statistical data analysis}

Raw data on inflammation was obtained, recorded and entered into a spreadsheet. Descriptive statistics were computed and the data expressed as mean \pm SEM. Inferential statistics were done using One-Way Analysis of Variance (ANOVA), followed by Tukey's post hoc test for pairwise comparison and separation of means. The anti-inflammatory activities of the two DCM plant extracts wre compared using the unpaired student t-test.
The level of significance was set at $99.5 \%(\mathrm{p} \leq 0.005)$.

\section{Results}

Quantitative phytochemical analysis of anti-inflammatory compounds of E. globulus and S. didymobotrya.

The GC-MS analysis of the DCM leaf extract of E. globulus (Labill) revealed the presence of several bioactive chemical compounds that have potential anti-inflammatory activities (Table 2).

Table 2 Phytochemical composition of anti-inflammatory compounds of E. globulus and S. didymobotrya

\begin{tabular}{llllll}
\hline $\begin{array}{l}\text { Compound } \\
\text { name }\end{array}$ & Chemical class & $\begin{array}{l}\text { E.globulus } \\
\text { Retention time (min) }\end{array}$ & $\begin{array}{c}\text { \% abundance } \\
\text { S.didymobotrya } \\
\text { Retention time } \\
(\mathbf{m i n})\end{array}$ & \% abundance \\
\hline Borneol & Mono terpenoids & 14.12 & 0.90 & - & - \\
$\begin{array}{l}\text {-terpineol } \\
\text { Terpinolene }\end{array}$ & Mono terpenoids & 14.57 & 1.06 & - & - \\
Aromadendrene & Terpenoids & 12.80 & 0.93 & 12.82 & 4.66 \\
$\begin{array}{l}\text { Camphene } \\
\text { alpha- } \\
\text { phellandrene }\end{array}$ & Terpenoids & 18.04 & 1.95 & - & - \\
Limonene & Terpenoids & 11.26 & 2.01 & 10.11 & 9.11 \\
Alpha-pinene & Terpenoids & 9.78 & 12.73 & 11.26 & 3.24 \\
\hline
\end{tabular}


Anti-inflammatory effects of DCM leaf extracts of E. globulus (Labill) and S. didymobotrya (Fresenius) on carrageenan-induced inflammation in mice

Generally, the administered doses of the DCM leaf extracts of E. globulus (Labill) and S. didymobotrya reduced carrageenan-induced edema in Swiss albino mice. This was evidenced by decreases in the circumference of inflamed paw after administration of the extracts.

In the $1^{\text {st }}$ hour, the DCM leaf extract of E. globulus (Labill), at the five doses of 50, 100, 150, 200 and 250 $\mathrm{mg} / \mathrm{kg}$ bw, reduced the inflamed paw in a dose-related manner by $0.85 \%, 1.45 \%, 1.41 \%, 2.02 \%$ and 2.27 $\%$ respectively (Table 3 ). However, the extract dose of $25 \mathrm{mg} / \mathrm{kg}$ bw did not reduce inflammation (Table 3). At this hour, the anti-inflammatory activity of E. globulus extract at doses of 50,100,150, 200 and $250 \mathrm{mg} / \mathrm{kg}$ bw was statistically similar and comparable to the activity of diclofenac sodium as presented in Table $3(p$ $>0.005$ ).

In the second hour, the E. globulus (Labill) extract, at the doses of 50,100,150, 200 and $250 \mathrm{mg} / \mathrm{kg}$ bw, reduced the paw edema in mice by $1.87 \%, 3.86 \%, 4.70 \%, 5.90 \%$ and $6.52 \%$ respectively (Table 3 ). However, at this hour, the E. globulus (Labill) extract dose of $25 \mathrm{mg} / \mathrm{kg}$ body weight exhibited no anti-inflammatory effects. There was a significant variation in the anti-inflammatory effect of E. globulus extract at the six dosages $(p<0.005$; Table 3). However, the anti-inflammatory activity of diclofenac was not significantly different compared to that of DCM extract of E. globulus (Labill) at the dose levels of 200 and $250 \mathrm{mg} / \mathrm{kg}$ body weight as presented in Table 3 ( $\mathrm{p}>0.005)$.

In the $3^{\text {rd }}$ hour, the E. globulus extract doses of 25,50 , $100,150,200$ and $250 \mathrm{mg} / \mathrm{kg}$ bw reduced the inflamed paw of animals by $1.28 \%, 3.22 \%, 5.80 \%, 7.35 \%, 8.70 \%$ and $9.09 \%$ respectively (Table 3 ). The anti-inflammatory effects of the six dose levels of E. globulus DCM leaf extract exhibited significant differences $(p<0.005$; Table 3). However, the anti-inflammatory effect of the reference drug was comparable to those of the E. globulus extract doses of 150, 200 and $250 \mathrm{mg} / \mathrm{kg}$ bw as shown in Table 3 ( $\mathrm{p}>0.005)$.

In the $4^{\text {th }}$ hour, the E. globulus extract doses of 25,50 , $100,150,200$ and $250 \mathrm{mg} / \mathrm{kg}$ bw decreased the inflamed paw circumference in mice models by $2.72 \%$, $3.89 \%, 6.13 \%, 8.60 \%, 9.94 \%$ and $10.90 \%$ respectively (Table 3). There were significant variations in the anti-inflammatory effects of E. globulus extract at all the six tested doses in mice ( $p<0.005$; Table 3). However, the anti-inflammatory effect of diclofenac was statistically similar to those of the E. globulus extract doses of 150, 200 and $250 \mathrm{mg} / \mathrm{kg}$ bw ( $\mathrm{p}>0.005$; Table 3). Generally, the E. globulus extract exhibited a dose-dependent response at all the hours tested (Table 3). Notably, the percentage paw circumference in the negative control group mice was significantly higher compared to those of extract-treated mice as well as those of rats in the positive control and normal control groups $(\mathrm{p}<0.005$; Table 3).

Table 3 Anti-inflammatory effect of dichloromethane leaf extract of E. globulus (Labill) on carrageenan-induced inflammation in Swiss albino mice.

\begin{tabular}{|c|c|c|c|c|c|c|}
\hline \multirow[t]{2}{*}{ Group } & \multirow[t]{2}{*}{ Treatment } & \multicolumn{5}{|c|}{ Percentage change in paw circumference $(\mathrm{mm})$} \\
\hline & & $0 \mathrm{~h}$ & $1 \mathrm{~h}$ & $2 \mathrm{~h}$ & $3 \mathrm{~h}$ & $4 \mathrm{~h}$ \\
\hline $\begin{array}{l}\text { Normal } \\
\text { control }\end{array}$ & DMSO (vehicle) & $100.00 \pm 0.00$ & $\begin{array}{l}100.00 \pm 0.00^{\mathrm{kc}} \\
(0.00)\end{array}$ & $\begin{array}{l}100.00 \pm 0.00^{b} \\
(0.00)\end{array}$ & $\begin{array}{l}100.00 \pm 0.00^{b} \\
(0.00)\end{array}$ & $\begin{array}{c}100.00 \pm 0.00 \\
(0.00)\end{array}$ \\
\hline $\begin{array}{l}\text { Negative } \\
\text { control }\end{array}$ & Carrageenan + DMSO only & $100.00 \pm 0.00$ & $\begin{array}{l}103.06 \pm 0.44^{a} \\
(-3.06)\end{array}$ & $\begin{array}{l}106.65 \pm 0.42^{\mathrm{a}} \\
\quad(-6.65)\end{array}$ & $\begin{array}{l}108.18 \pm 0.36^{\mathrm{a}} \\
(-8.18)\end{array}$ & $\begin{array}{c}109.11 \pm 0.39^{\mathrm{a}} \\
(-9.11)\end{array}$ \\
\hline $\begin{array}{l}\text { Positive } \\
\text { control }\end{array}$ & $\begin{array}{l}\text { Carrageenan + Diclofenac }(15 \mathrm{mg} / \mathrm{kg} \\
\text { bw) }\end{array}$ & $100.00 \pm 0.00$ & $\begin{array}{l}98.23 \pm 0.15^{d} \\
\quad(1.77)\end{array}$ & $\begin{array}{l}93.57 \pm 0.23^{\mathrm{f}} \\
\quad(6.43)\end{array}$ & $\begin{array}{l}92.11 \pm 0.32^{\text {ef }} \\
(7.89)\end{array}$ & $\begin{array}{l}90.03 \pm 0.17^{\text {ef }} \\
(9.97)\end{array}$ \\
\hline \multirow[t]{6}{*}{$\begin{array}{l}\text { DCM leaf } \\
\text { extract }\end{array}$} & Carrageenan $+25 \mathrm{mg} / \mathrm{kg}$ bw & $100.00 \pm 0.00$ & $\begin{array}{c}100.81 \pm 0.50^{b} \\
(-0.81)\end{array}$ & $\begin{array}{c}100.15 \pm 0.31^{\mathrm{b}} \\
(-0.15)\end{array}$ & $\begin{array}{l}98.72 \pm 0.20^{\circ} \\
(1.28)\end{array}$ & $\begin{array}{l}97.28 \pm 0.15 \\
(2.72)\end{array}$ \\
\hline & Carrageenan $+50 \mathrm{mg} / \mathrm{kg}$ bw & $100.00 \pm 0.00$ & $\begin{array}{l}99.15 \pm 0.01^{\mathrm{dd}} \\
\quad(0.85)\end{array}$ & $\begin{array}{l}98.13 \pm 0.18 \mathrm{c} \\
(1.87)\end{array}$ & $\begin{array}{l}96.78 \pm 0.17 \\
(3.22)\end{array}$ & $\begin{array}{l}96.11 \pm 0.30^{\circ} \\
(3.89)\end{array}$ \\
\hline & Carrageenan $+100 \mathrm{mg} / \mathrm{kg}$ bw & $100.00 \pm 0.00$ & $\begin{array}{l}98.55 \pm 0.16^{\mathrm{cd}} \\
(1.45)\end{array}$ & $\begin{array}{l}96.14 \pm 0.27^{d} \\
(3.86)\end{array}$ & $\begin{array}{l}94.20 \pm 0.34^{d} \\
(5.80)\end{array}$ & $\begin{array}{l}93.87 \pm 0.19^{\mathrm{d}} \\
\quad(6.13)\end{array}$ \\
\hline & Carrageenan $+150 \mathrm{mg} / \mathrm{kg}$ bw & $100.00 \pm 0.00$ & $\begin{array}{l}98.59 \pm 0.15^{\mathrm{cd}} \\
(1.41)\end{array}$ & $\begin{array}{l}95.30 \pm 0.04^{\text {di }} \\
(4.70)\end{array}$ & $\begin{array}{c}92.65 \pm 0.17^{\circ} \\
(7.35)\end{array}$ & $\begin{array}{l}91.40 \pm 0.44{ }^{\circ} \\
(8.60)\end{array}$ \\
\hline & Carrageenan $+200 \mathrm{mg} / \mathrm{kg}$ bw & $100.00 \pm 0.00$ & $\begin{array}{l}97.98 \pm 0.18^{\mathrm{d}} \\
(2.02)\end{array}$ & $\begin{array}{l}94.10 \pm 0.22^{\text {ef }} \\
(5.90)\end{array}$ & $\begin{array}{l}91.30 \pm 0.18^{\text {of }} \\
(8.70)\end{array}$ & $\begin{array}{l}90.06 \pm 0.32^{2 f} \\
(9.94)\end{array}$ \\
\hline & Carrageenan $+250 \mathrm{mg} / \mathrm{kg}$ bw & $100.00 \pm 0.00$ & $\begin{array}{l}97.73 \pm 0.23^{\mathrm{d}} \\
(2.27)\end{array}$ & $\begin{array}{l}93.48 \pm 0.20 \\
(6.52)\end{array}$ & $\begin{array}{l}90.91 \pm 0.34 \\
(9.09)\end{array}$ & $\begin{array}{l}89.10 \pm 0.19 \\
(10.90)\end{array}$ \\
\hline
\end{tabular}

Descriptive statistics expressed as mean \pm SEM for five mice in every group. Values that have different superscript letters are statistically significant along the same column by one-way ANOVA accompanied by Tukey's post hoc test $(\mathrm{p} \leq 0.005)$. The values in brackets represent $\%$ inflammation inhibition. 
On the other hand, the DCM leaf extract of $S$. didymobotrya, at the six tested doses demonstrated anti-inflammatory effects on carrageenan-induced inflammation in Swiss albino mice (Table 4). In the first hour, the DCM extract of $S$. didymobotrya extract doses of 100, 150, 200 and $250 \mathrm{mg} / \mathrm{kg}$ bw decreased the inflamed paw circumference in mice by $1.11 \%, 1.40 \%, 2.14 \%$ and $2.41 \%$ respectively. However, the extract never exhibited anti-inflammatory effects at 25 and $50 \mathrm{mg} / \mathrm{kg}$ body weight dose levels (Table 4). The anti-inflammatory activities of the $S$. didymobotrya extract doses of 100,150, 200 and $250 \mathrm{mg} / \mathrm{kg}$ body weight exhibited no significant differences ( $p>0.005$; Table 4). Similarly, the anti-inflammatory activity of the reference drug (diclofenac) was comparable to those of $S$. didymobotrya extract doses of 150, 200 and $250 \mathrm{mg} / \mathrm{kg}$ bw (Table 4; $\mathrm{p}>0.005$ ).

In the $2^{\text {nd }}$ hour, the DCM leaf extract of $S$. didymobotrya, at doses of 50,100, 150, 200 and $250 \mathrm{mg} / \mathrm{kg}$ bw, decreased the inflamed paw circumference in mice by $0.50 \%, 2.54 \%, 3.71 \%, 4.12 \%$ and $5.13 \%$ respectively (Table 4). However, the extract dose level of $25 \mathrm{mg} / \mathrm{kg}$ body weight never revealed anti-inflammatory activity (Table 4). The anti-inflammatory activity of the tested doses of $S$. didymobotrya extract exhibited significant differences in mice $(p<0.005$; Table 4). However, the anti-inflammatory activity of diclofenac was statistically insignificant compared to that of $S$. didymobotrya at the doses of 200 and $250 \mathrm{mg} / \mathrm{kg}$ bw (p > 0.005; Table 4).

In the 3rd hour, the $\mathrm{S}$. didymobotrya extract at doses of $25,50,100,150,200$ and $250 \mathrm{mg} / \mathrm{kg}$ bw reduced the inflamed paw circumference by $1.13 \%, 1.99 \%, 3.81 \%$, $5.11 \%, 5.50 \%$ and $8.31 \%$ respectively (Table 4 ). The anti-inflammatory effects of $S$. didymobotrya extract exhibited significant differences at the six tested doses at this hour $(\mathrm{p}<0.005$; Table 4). However, the effect of the diclofenac was comparable to that of the DCM extract of $S$. didymobotrya at the dose level of $250 \mathrm{mg} / \mathrm{kg}$ bw in Swiss albino mice ( $p>0.005$; Table 4).

The $S$. didymobotrya extract doses of $25,50,100,150$, 200 and $250 \mathrm{mg} / \mathrm{kg}$ body weight reduced the inflamed paw circumference by $2.59 \%, 3.16 \%, 4.61 \%, 6.34 \%$, $7.03 \%$ and $9.05 \%$ respectively in the fourth hour (Table 4). At this hour, there was a significant variation in the anti-inflammatory effects of $S$. didymobotrya extract in mice at the six tested doses $(\mathrm{p}<0.005$; Table 4). However, the anti-inflammatory effect of the reference drug, diclofenac, was comparable to that of extract at dose of $250 \mathrm{mg} / \mathrm{kg}$ body weight ( $\mathrm{p}>0.005$; Table 4$)$. Generally, the percentage paw circumference in the negative control group mice was significantly higher compared to extract-treated mice as well as mice in the positive and normal control groups ( $p<0.005$; Table 4).

Table 4 Anti-inflammatory effect of dichloromethane leaf extract of $S$. didymobotrya (Fresenius) on carrageenan-induced inflammation in Swiss albino mice.

\begin{tabular}{|c|c|c|c|c|c|c|}
\hline \multirow[t]{2}{*}{ Group } & \multirow[t]{2}{*}{ Treatment } & \multicolumn{4}{|c|}{ Percentage change in paw circumference $(\mathrm{mm})$} & \multirow[b]{2}{*}{$4 \mathrm{~h}$} \\
\hline & & $\mathbf{0 h}$ & $1 \mathrm{~h}$ & $2 \mathrm{~h}$ & $3 \mathbf{h}$ & \\
\hline $\begin{array}{l}\text { Normal } \\
\text { control }\end{array}$ & DMSO (vehicle) & $100.00 \pm 0.00$ & $\begin{array}{c}100.00 \pm 0.00^{\mathrm{b}} \\
(0.00)\end{array}$ & $\begin{array}{c}100 \pm 0.00^{b} \\
(0.00)\end{array}$ & $\begin{array}{c}100.00 \pm 0.00^{\mathrm{b}} \\
(0.00)\end{array}$ & $\begin{array}{c}100.00 \pm 0.00^{\mathrm{b}} \\
(0.00)\end{array}$ \\
\hline $\begin{array}{l}\text { Negative } \\
\text { Control }\end{array}$ & Carrageenan + DMSO & $100.00 \pm 0.00$ & $\begin{array}{c}102.86 \pm 0.41^{\mathrm{a}} \\
(-2.86)\end{array}$ & $\begin{array}{c}106.54 \pm 0.42^{\mathrm{a}} \\
(-6.54)\end{array}$ & $\begin{array}{c}108.40 \pm 0.29^{\mathrm{a}} \\
(-8.40)\end{array}$ & $\begin{array}{c}109.51 \pm 0.36^{\mathrm{a}} \\
(-9.51)\end{array}$ \\
\hline $\begin{array}{l}\text { Positive } \\
\text { Control }\end{array}$ & $\begin{array}{l}\text { Carrageenan + (Diclofenac } \\
15 \mathrm{mg} / \mathrm{kgbw})\end{array}$ & $100.00 \pm 0.00$ & $\begin{array}{l}97.27 \pm 0.0 .21^{\circ} \\
\quad(2.73)\end{array}$ & $\begin{array}{l}94.53 \pm 0.41^{d} \\
(5.47)\end{array}$ & $\begin{array}{l}92.95 \pm 0.21^{\mathrm{f}} \\
(7.05)\end{array}$ & $\begin{array}{l}91.98 \pm 0.16^{\mathrm{fg}} \\
(8.02)\end{array}$ \\
\hline \multirow[t]{6}{*}{$\begin{array}{l}\text { DCM:leaf } \\
\text { Extract }\end{array}$} & Carrageenan $+25 \mathrm{mg} / \mathrm{kgbw}$ & $100.00 \pm 0.00$ & $\begin{array}{c}101.30 \pm 0.0 .33^{b} \\
(-1.30)\end{array}$ & $\begin{array}{c}100.50 \pm 0.20^{\mathrm{b}} \\
(-0.50)\end{array}$ & $\begin{array}{c}98.87 \pm 0.20^{\text {bc }} \\
\quad(1.13)\end{array}$ & $\begin{array}{c}97.41 \pm 0.19^{\circ} \\
(2.59)\end{array}$ \\
\hline & Carrageenan $+50 \mathrm{mg} / \mathrm{kgbw}$ & $100.00 \pm 0.00$ & $\begin{array}{l}100.50 \pm 0.20^{b} \\
(-0.50)\end{array}$ & $\begin{array}{c}99.50 \pm 0.20^{\circ} \\
(0.50)\end{array}$ & $\begin{array}{c}98.01 \pm 0.20^{\circ} \\
(1.99)\end{array}$ & $\begin{array}{c}96.84 \pm 0.16^{\circ} \\
(3.16)\end{array}$ \\
\hline & Carrageenan $+100 \mathrm{mg} / \mathrm{kgbw}$ & $100.00 \pm 0.00$ & $\begin{array}{l}99.89 \pm 0.20^{\mathrm{cd}} \\
(1.11)\end{array}$ & $\begin{array}{l}97.46 \pm 0.15^{\circ} \\
(2.54)\end{array}$ & $\begin{array}{c}96.19 \pm 0.29^{d} \\
(3.81)\end{array}$ & $\begin{array}{c}95.39 \pm 0.16^{d} \\
(4.61)\end{array}$ \\
\hline & Carrageenan $+150 \mathrm{mg} / \mathrm{kgbw}$ & $100.00 \pm 0.00$ & $\begin{array}{l}98.60 \pm 0.15^{\mathrm{de}} \\
(1.40)\end{array}$ & $\begin{array}{l}96.29 \pm 0.15^{\circ} \\
\quad(3.71)\end{array}$ & $\begin{array}{l}94.89 \pm 0.21^{\mathrm{de}} \\
\quad(5.11)\end{array}$ & $\begin{array}{c}93.66 \pm 0.27^{\circ} \\
(6.34)\end{array}$ \\
\hline & Carrageenan $+200 \mathrm{mg} / \mathrm{kgbw}$ & $100.00 \pm 0.00$ & $\begin{array}{l}97.86 \pm 0.16^{\mathrm{de}} \\
(2.14)\end{array}$ & $\begin{array}{c}95.88 \pm 0.38^{\mathrm{cd}} \\
(4.12)\end{array}$ & $\begin{array}{c}94.50 \pm 0.13^{e} \\
\quad(5.50)\end{array}$ & $\begin{array}{l}92.97 \pm 0.24^{\text {ef }} \\
(7.03)\end{array}$ \\
\hline & Carrageenan $+250 \mathrm{mg} / \mathrm{kgbw}$ & $100.00 \pm 0.00$ & $\begin{array}{l}97.59 \pm 0.13^{\mathrm{de}} \\
(2.41)\end{array}$ & $\begin{array}{c}94.57 \pm 0.27^{d} \\
(5.43)\end{array}$ & $\begin{array}{l}91.69 \pm 0.41^{\mathrm{f}} \\
(8.31)\end{array}$ & $\begin{array}{c}90.95 \pm 0.32^{\mathrm{s}} \\
(9.05)\end{array}$ \\
\hline
\end{tabular}

Descriptive statistics expressed as mean \pm SEM for five mice in every group. Descriptive statistics that have different superscript letters are statistically significant along the same column by one-way analysis of variance accompanied by Tukey's post hoc test $(p \leq 0.005)$. The values in brackets represent $\%$ inflammation inhibition. 
Comparison between anti-inflammatory activities of DCM extracts of E. globulus (Labill) and S. didymobotrya (Fresenius)

In comparison, the anti-inflammatory activities of the
DCM leaf extracts of the two plant extracts in mice, at the dose of $25 \mathrm{mg} / \mathrm{kg}$ body weight, were not significantly different in the four hours of the test period $(p$ $>0.005$; Figure 2).

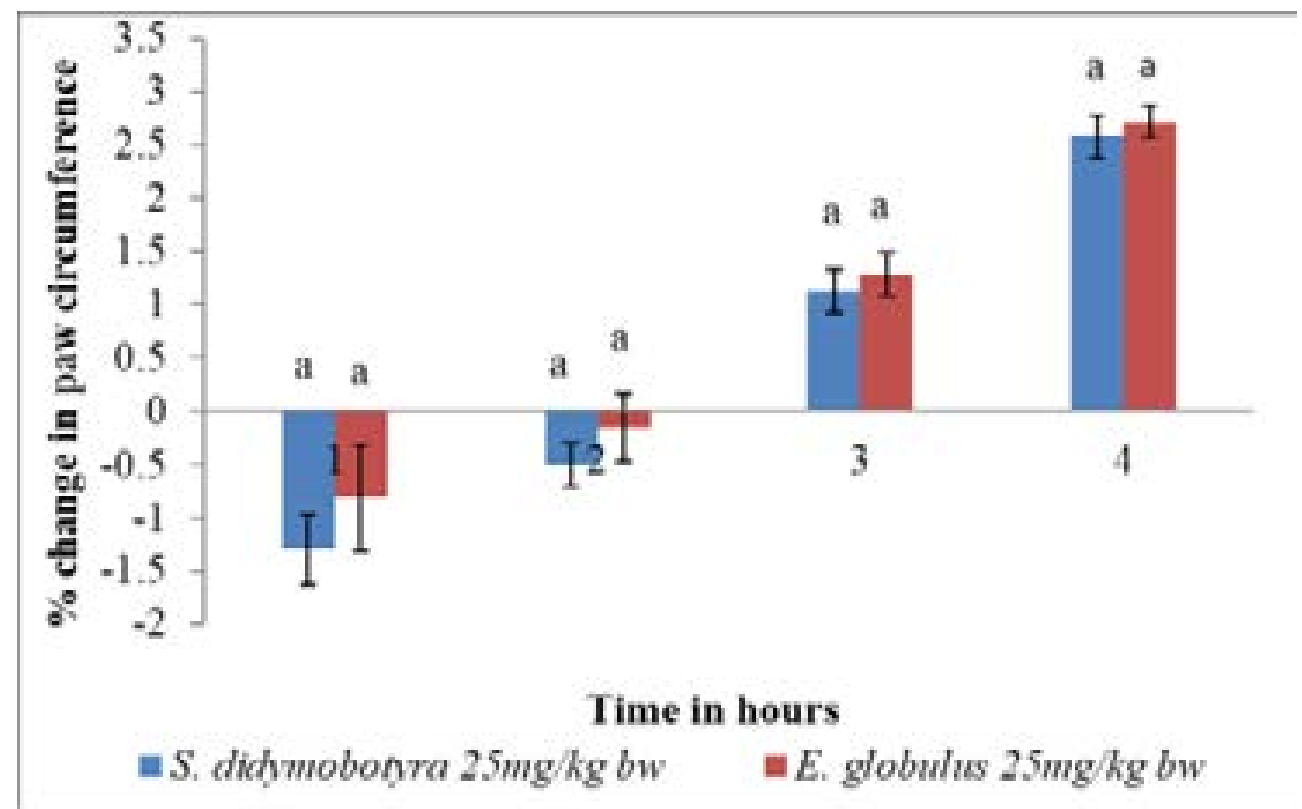

Figure 2 Comparison of anti-inflammatory activity of E. globulus (Labill) and S. didymobotyra (Fresenius) DCM leaf extracts at $25 \mathrm{mg} / \mathrm{kgbw}$ on carrageenan-induced inflammation in mice. Means with different letters are statistically significant in each hour of treatment $(p \leq 0.005)$. bw = bodyweight

Comparatively, the anti-inflammatory activity of the E. el ( $<<0.005$; Figure 3$)$. However, at the same dose level, globulus extract dose level of $50 \mathrm{mg} / \mathrm{kg}$ body weight was significantly higher compared to that of $S$. didymobotyra the anti-inflammatory effects of E. globulus (Labill) and in the first, second and third hours at the same dose levS. didymobotyra (Fresenius) extracts showed no significant differences in the fourth hour $(\mathrm{p}>0.005$; Figure 3$)$.

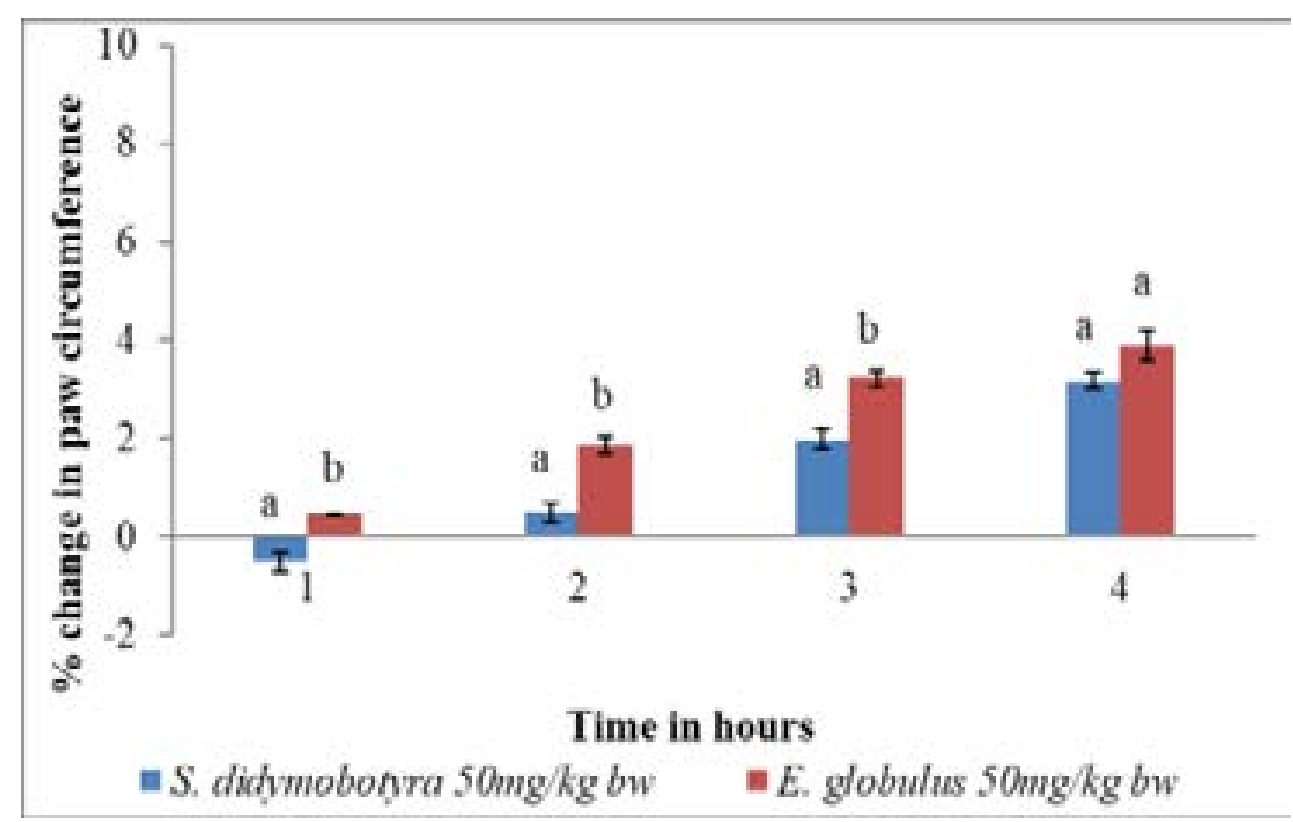

Figure 3 Comparison of anti-inflammatory activities of E.globulus (Labill) and S. didymobotyra (Fresenius) DCM leaf extracts at $50 \mathrm{mg} / \mathrm{kgbw}$ dose level on carrageenan-induced inflammation in mice. Means with different letters are statistically significant in each hour of treatment $(p \leq 0.005)$. bw = bodyweight 
At the dose level of $100 \mathrm{mg} / \mathrm{kg}$ body weight, the anti-inflammatory effects of DCM leaf extracts of E. globulus and $S$. didymobotyra were not significantly different in the first hour ( $p>0.005$; Figure 4). In contrast, the anti-in- flammatory effect of E. globulus extract was significantly higher compared to that of $S$. didymobotyra at the same dose in the second, third and fourth hours $(p \leq 0.005$; Figure 4).

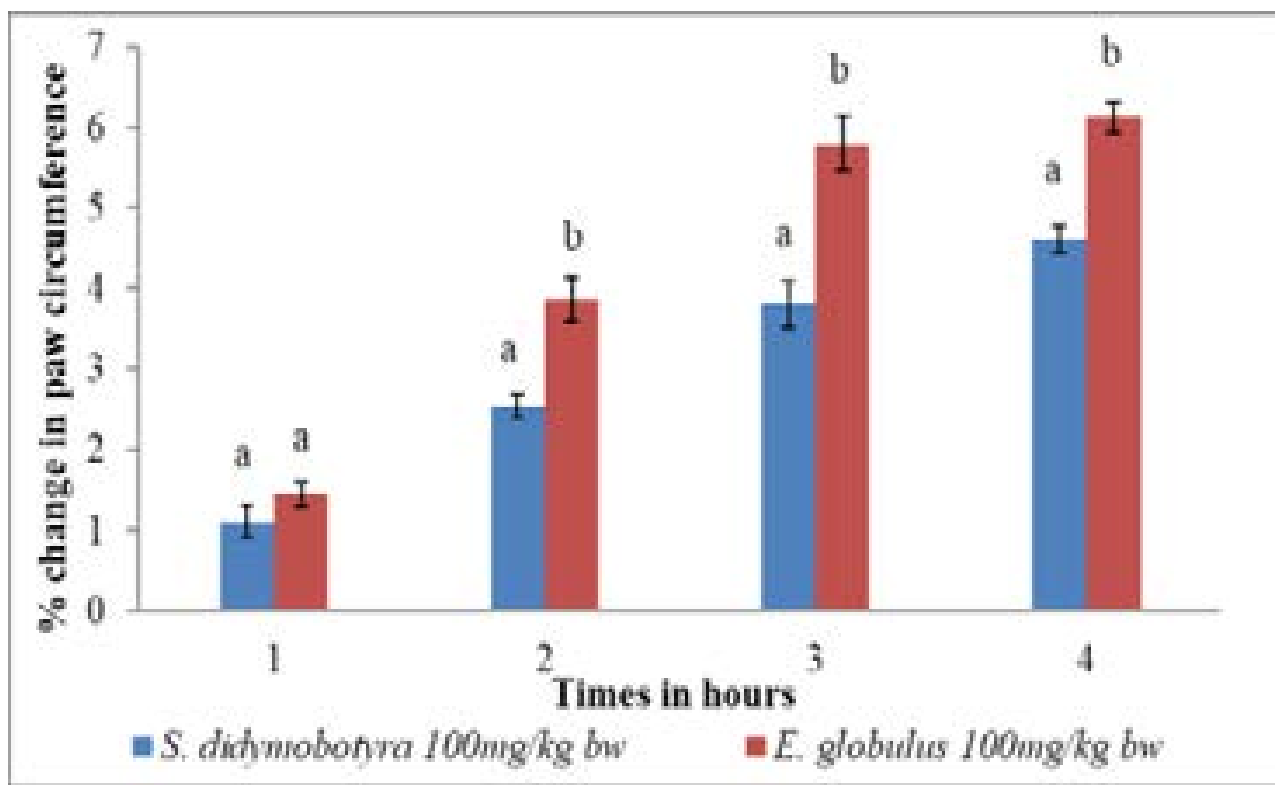

Figure 4 Comparison of anti-inflammatory effects of E. globulus (Labill) and S. didymobotyra (Fresenius) DCM leaf extracts at $100 \mathrm{mg} / \mathrm{kgbw}$ on carrageenan-induced inflammation in mice. Means with different letters are statistically significant in each hour of treatment $(p \leq 0.005)$. bw $=$ bodyweight.

The anti-inflammatory effects of E. globulus and S. didymobotyra extract dose levels of $150 \mathrm{mg} / \mathrm{kg}$ body weight revealed no significant difference in mice $(\mathrm{p}>0.005$;
Figure 5). However, the anti-inflammatory activity of E. globulus extract at the same dose was significantly higher compared to that of $S$. didymobotyra in the second, third and fourth hours ( $\mathrm{p} \leq 0.005$; Figure 5).

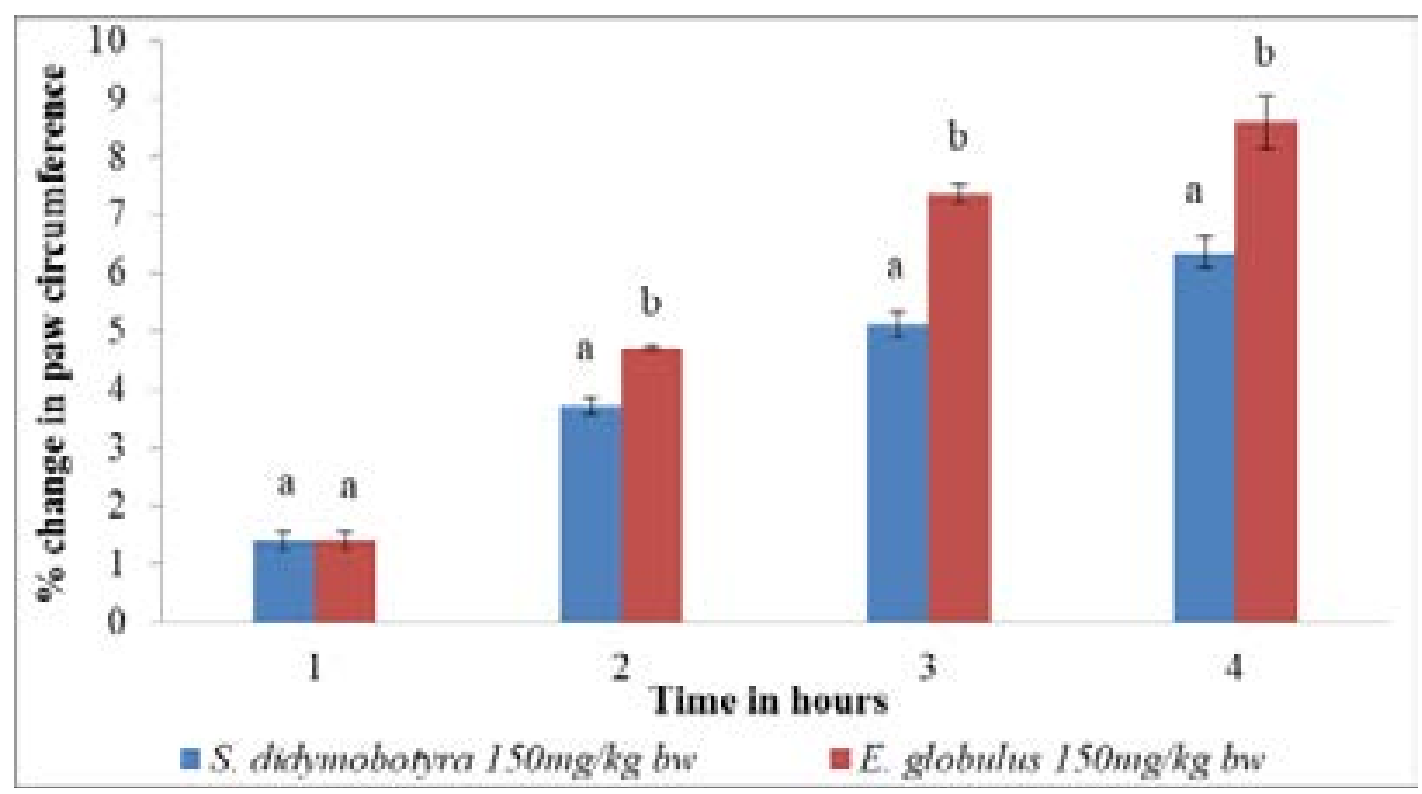

Figure 5 Comparison of anti-inflammatory effects of E. globulus (Labill) and S. didymobotyra (Fresenius) DCM leaf extracts at $150 \mathrm{mg} / \mathrm{kgbw}$ on carrageenan-induced inflammation in mice. Means with different letters are statistically significant in each hour of treatment $(p \leq 0.005)$. $b w=$ bodyweight. 
There was insignificant variation in the anti-inflammatory effects of E. globulus and S. didymobotyra extract doses of $200 \mathrm{mg} / \mathrm{kg}$ body weight in the first and second hours ( $p>0.005$; Figure 6). However, the anti-inflammatory effects of the E. globlus extract, at the same dose level, were significantly higher than that of $S$. didymobotyra in the third and fourth hours $(\mathrm{p}<0.005$; Figure 6$)$.

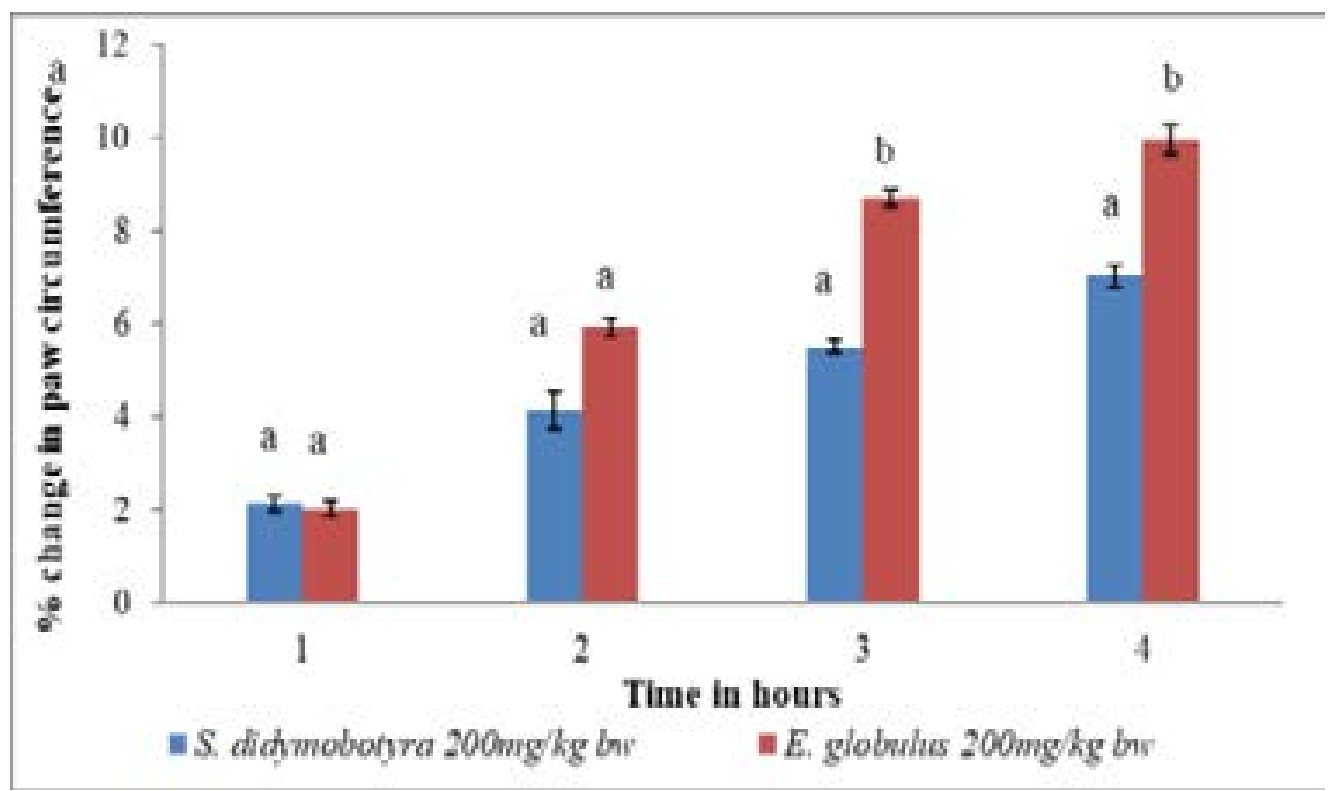

Figure 6 Comparison of anti-inflammatory effects of E. globulus (Labill) and S. didymobotyra (Fresenius) DCM leaf extracts at $200 \mathrm{mg} / \mathrm{kgbw}$ on carrageenan-induced inflammation in mice.

Means with different letters are statistically significant in each hour of treatment $(p \leq 0.005)$. bw $=$ bodyweight.

At the dose level of $250 \mathrm{mg} / \mathrm{kg}$ body weight, the anti-inflammatory effects of DCM leaf extracts of E. globulus and $S$. didymobotyra in mice were statistically similar in the first, second and third hours ( $p>0.005$; Figure 7). However, in the fourth hour, there was an insignificant variation in the anti-inflammatory effects of the two plant extracts $(\mathrm{p}<0.005$; Figure 7$)$.

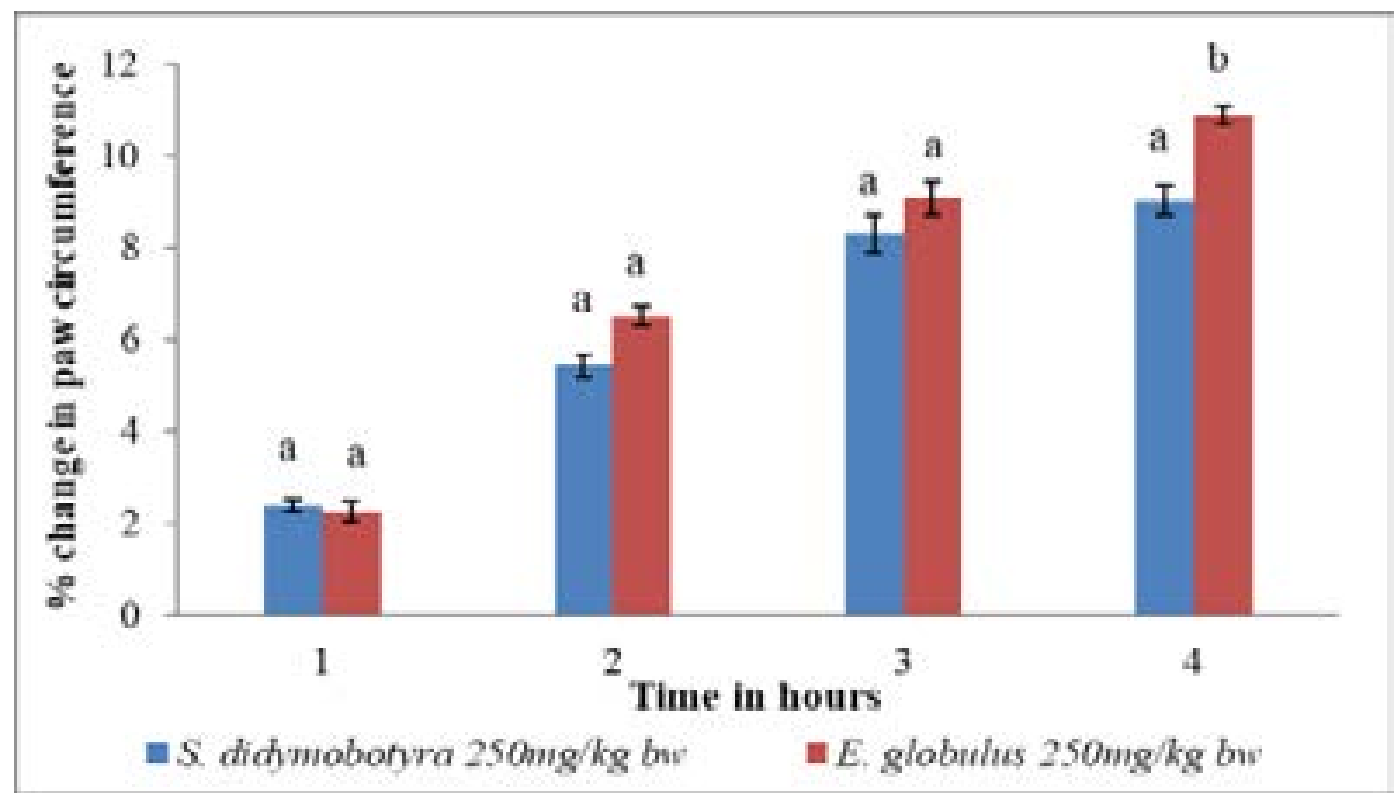

Figure 7 Comparison of anti-inflammatory effects of $E$. globulus (Labill) and $S$. didymobotyra (Fresenius) DCM leaf extracts at $250 \mathrm{mg} / \mathrm{kgbw}$ on carrageenan-induced inflammation in mice. Means with different letters are statistically insignificant in each hour of treatment $(\mathrm{p} \leq 0.005)$. $\mathrm{bw}=$ bodyweight. 


\section{Discussion}

The present study was designed to determine anti-inflammatory potential of dichloromethane leaf extracts of E. globulus (Labill) and S. didymobotrya (Fresenius) in mice models. The studied plants are used by Mbeere community in Embu County, Kenya in the management of inflammation but no scientific research data is available to confirm their use.

Inflammation is a complex protective reaction of the body against noxious agents like microorganisms or injured cells ${ }^{21}$. Carrageenan-induced paw inflammation is the most suitable model in the determination of the anti-inflammatory activities of different agents that act by blocking the acute inflammatory mediators in vivo ${ }^{22}$. Carrageenan induces inflammation in two phases ${ }^{23}$. The early phase, which occurs between ninety to one hundred and eighty minutes of the inflammation, is as a result of the discharge of serotonin, histamine among other substances while the late, phase which occurs between 270 to 360 minutes, is postulated to be linked with the activation of the lysosome, prostaglandins and 62 proteases $^{24}$.

The NSAIDs like diclofenac reduce edema by blocking enzyme cyclooxygenase (COX), which catalyzes prostaglandin biosynthesis ${ }^{25}$. Cyclooxygenase enzymes exist in two forms; cyclooxygenase-1 and cyclooxygenase- 2 . These two enzymes catalyze the synthesis of prostaglandins, which stimulate inflammation. The NSAIDs blocks the cyclooxygenase enzymes and decrease prostaglandin levels in the entire body, leading to a reduction of inflammation ${ }^{26,27}$.

These study findings revealed that the E. globulus (Labill) and $S$. didymobotyra (Fresenius) DCM leaf extracts possess anti-inflammatory effects, which were evident by the reduction of inflamed paw circumference in mice models after treatment. These findings are consistent with earlier research works on the anti-inflammatory effects of other herbal plants in experimental animals. A study by Owolabi et al. ${ }^{28}$ on anti-inflammatory activity of aqueous, ethanol, diethyl ether, n-Hexane root extracts of Feretia apodanthera on carrageenan-induced paw edema in rats, reported that this extract provided great relief by lowering edema in the inflamed paw. A study by Matthew et al. ${ }^{29}$, who carried out studies on pharmacological activities of ethanol and aqueous extracts of dried stem of plant Kalanchoe pinnata (Lam.) Pers against inflammation in rats revealed potent anti-inflammatory activities.
The anti-inflammatory effects of these plants are attributed to their constituent phytochemicals like terpenoids, flavonoids and essential oils. Other researchers have associated these phytochemicals with anti-inflammatory activities. A review by Andrade and De Sousa ${ }^{30}$, demonstrated that $\alpha$-Pinene possesses anti-inflammatory activity in mice. Another study by Bayala et al. ${ }^{31}$ revealed that essential oils possess anti-inflammatory activity in animal models. A study by Zou et al. ${ }^{32}$ revealed that borneol possesses significant anti-inflammatory activity. The results of GC-MS similarly revealed the presence of Alpha-terpineol. According to a study by Soleimani et al..$^{33}$, Alpha-terpineol possesses anti-inflammatory activity in rat models.

The results of the GC-MS also revealed the presence of terpinolene. A study by Aggarwal et al. ${ }^{34}$, has shown that terpinolene isolated from turmeric has an anti-inflammatory effect on formalin-induced arthritis, cotton pellet granuloma and granuloma pouch models of inflammation in rats. The results of GC-MS analysis also revealed the presence of $\alpha$-phellandrene. $\alpha$-phellandrene is a monoterpene that is part of the essential oils found in many plants. Additionally, Gbenou et al.35, demonstrated that Cymbopogon citratus and Eucalyptus citriodora contained essential oils that possess significant anti-inflammatory activity by reducing formol-induced paw edema in rats. Similarly, a review by Arruda et al. ${ }^{36}$ also reports the anti-inflammatory potential of $\alpha$-phellandrene. Further, the GC-MS results revealed the presence of Limonene. In a study by $\mathrm{Li}$ et al. ${ }^{37}$, on in vitro anti-inflammatory activity of Spondias pinnata (Anacardiaceae) on Nitric oxide production, indicated that $\mathrm{Li}$ monene possesses anti-inflammatory activity. Studies by Vieira et al. ${ }^{38}$, Rufino V. ${ }^{39}$, Khodabakhsh et al. ${ }^{40}$, also demonstrate that Limonene has great potential in the management of inflammation. According to a study by Jin et al. ${ }^{41}$, on the phytochemical composition of the cannabis plant and its use for medicinal purposes, it is reported that Aromadendrene and terpenoids possess anti-inflammatory effects.

\section{Limitations}

This study focused on in vivo anti-inflammatory effects of E. globulus (Labill) and S. didymobotrya (Fresenius) in mice and did not explore in vitro anti-inflammatory activity of these plant extracts. Secondly, extracts of other plant parts like roots and stems were not studied for comparison purposes. Further, the extraction solvent used in this study was Dichloromethane, a non-polar solvent. Use of a polar extraction solvent may probably yield superior results.

African Health Sciences, Vol 21 Issue 1, March, 2021 


\section{Conclusion}

This study has demonstrated that the dichloromethane leaf extracts of E. globulus (Labill) and S. didymobotrya (Fresenius) have anti-inflammatory activity in mice, which can be attributed to the constituent phytochemicals. This study confirms the traditional claim of anti-inflammatory activities of the two plants.

\section{Abbreviations \\ ANOVA $=$ Analysis of variance; DMSO $=$ Dimethyl sulfoxide; ICIPE = International Centre of Insect Physiology and Ecology; GC-MS = Gas chromatogra- phy-Mass spectrophotometry; DCM = Dichlorometh- ane; $\mathrm{Bw}=$ Body weight; $\mathrm{kg}=$ Kilogram; $\mathrm{MS}$ excel = Microsoft excel; NSAIDS = Non-Steroidal Anti-In- flammatory Drugs.}

\section{Acknowledgments}

Authors wish to thank Kenyatta University for availing the laboratories for animal breeding and experimentation using their facility and the International Centre of Insect Physiology and Ecology for allowing us uses their laboratory to carry out Gas chromatography-Mass spectrophotometry analysis of the plant extracts.

\section{Author contribution statement}

Joseph KM, Cromwell MK, Joseph NN and Mathew PN: designed the project, collected the specimen and performed the experiments, analyzed and data interpretation preparation of the manuscript.

\section{Conflicts of interest}

None declared.

\section{Funding}

No funding was received for this study from any funding body.

\section{References}

1. Chen L, Deng H, Cui H, Fang J, Zuo Z, Deng $\mathrm{J}$, et al. Inflammatory responses and inflammation-associated diseases in organs, Oncotarget 2018; 9(6):7204-7217.

2. Oishi Y, Manabe I. Macrophages in inflammation, repair and regeneration. International Immunology 2018; 30(11):511-528.

3. Chinese RD, Chinese SL. Recommendation for the prevention and treatment of non-steroidal anti-inflammatory drug-induced gastrointestinal ulcers and its complications. Zhonghua Nei Ke Za Zhi 2017; 56 (1): 8185.

4. Wehling M. Non-steroidal anti-inflammatory drug use in chronic pain conditions with special emphasis on the elderly and patients with relevant comorbidities: management and mitigation of risks and adverse effects. European Journal of Clinical Pharmacology 2014; 70 (10):1159-1172.

5. Antonisamy P, Duraipandiyan V, Ignacimuthu S. Anti-inflammatory, analgesic and antipyretic effects of friedelin isolated from Azima tetracantha Lam. in mouse and rat models. Journal of Pharmacy and Pharmacology. 2011;63(8):1070-7.

6. Latief N, Anand S, Lingaraju MC, Balaganur V, Pathak NN, Kalra J, et al. Effect of Trimeric Myricetin Rhamnoside (TMR) in Carrageenan-induced Inflammation and Caecal Ligation and Puncture-induced Lung Oxidative Stress in Mice. Phytotherapy Research. 2015;29(11):1798-805.

7. Jiang TA. Health Benefits of Culinary Herbs and Spices. Journal of AOAC International 2019; 102 (2):395-411.

8. Shaffique S, Rehman A, Ahmed S, Hussain G, Anwar H, Muhammad AH. Review on Pharmacological Activities and Homeopathic Uses of Eucalyptus globulus. RADS Journal of Pharmacy and Pharmaceutical Sciences 2018; 6 (2): 157-161.

9. Dutkowski GW, Potts BM. Genetic variation in the susceptibility of Eucalyptus globulus to drought damage. Tree Genetics \& Genomes 2012; 8 (4): 757-773.

10. Anthoney TS, Ngule CM, Obey J. Qualitative assessment of phytochemicals of infused Senna didymobotrya leaves. International Journal of Pharmacology 2014; 4 (1): 40-45.

11. Jeruto P, Arama PF, Anyango B, Maroa G. Phytochemical screening and antibacterial investigations of crude methanol extracts of Senna didymobotrya (Fresen.) HS Irwin \& Barneby. Journal of Applied Biosciences 2017; 114 (1): 11357-11367.

12. Sun J, Wu Y, Dong S, Li X, Gao W. Influence of the drying method on the bioactive compounds and pharmacological activities of Rhubarb. Journal of the Science of Food and Agriculture 2018; 98 (9): 3551-3562.

13. McCloud TG. High throughput extraction of plant, marine and fungal specimens for preservation of biologically active molecules. Molecules 2010; 15 (7): 4526-4563.

14. Bao Q, Fu K, Ren Q, Zhong Y, Qian D. Accuracy Profiles for Analyzing Residual Solvents in Textiles by GC-MS. Journal of Chromatographic Science 2017; 55(9): 882-890.

15. Fotso AF, Longo F, Djomeni PD, Kouam SF, Spiteller M, Dongmo AB, et al. Analgesic and antiinflammatory activities of the ethyl acetate fraction 
of Bidens pilosa (Asteraceae). Inflammopharmacology. 2014;22(2):105-14.

16. Limban C, Missir AV, Fahelelbom KM, Al-Tabakha MM, Caproiu MT, Sadek B.Novel N-phenylcarbamothioylbenzamides with anti-inflammatory activity and prostaglandin E2 inhibitory properties. Drug design, development and therapy. 2013;7:883

17. Aragão DM, Guarize L, Lanini J, da Costa JC, Garcia RM, Scio E. Hypoglycemic effects of Cecropia pachystachya in normal and alloxan-induced diabetic rats. Journal of Ethnopharmacology 2010; 128(3): 629-633.

18. Dash S, Sahoo AC, Mishra B. In vitro and In vivo Antioxidant assessment and Hepatoprotective activity of Aponogeton natans (Linn.) Engl. and Krause on Diclofenac sodium induced liver toxicity. Research Journal of Pharmacy and Technology 2018; 11(10): 44314438.

19. da Silva AO, Alves AD, de Almeida DA, Balogun SO, de Oliveira RG, Aguiar AA, et al. Evaluation of anti-inflammatory and mechanism of action of extract of Macrosiphonia longiflora (Desf.) Müll. Arg. Journal of Ethnopharmacology 2014; 154 (2): 319-329.

20. Umamageswari A, Kudagi BL. Anti-inflammatory and analgesic properties of Ocimum sanctum: a comparative study using animal models. International Journal of Basic and Clinical Pharmacology, 2015 4: 981-986. 21. Sofidiya MO, Imeh E, Ezeani C, Aigbe FR, Akindele AJ. Antinociceptive and anti-inflammatory activities of ethanolic extract of Alafia barteri. Revista Brasileira de Farmacognosia 2014; 24 (3): 348-354.

22. Kuprash DV, Nedospasov SA. Molecular and cellular mechanisms of inflammation. Biochemistry (Moscow) 2016; 81(11):1237-1239.

23. Mayor AR, Cruz-Antonio L, Castañeda-Hernández G, Favari-Perozzi L, Guízar-Sahagún G. Time-dependent changes in paw carrageenan-induced inflammation above and below the level of low thoracic spinal cord injury in rats. Spinal Cord 2018; 56(10): 964970.

24. Yang J, Bae HB, Ki HG, Oh JM, Kim WM, Lee HG, et al. Different role of spinal 5-HT (hydroxytryptamine) 7 receptors and descending serotonergic modulation in inflammatory pain induced in formalin and carrageenan rat models. British Journal of Anaesthesia 2014; 113 (1): 138-147.

25. Jitta SR, Daram P, Gourishetti K, Misra CS, Polu PR, Shah A, et al. Terminalia tomentosa Bark Ameliorates Inflammation and Arthritis in Carrageenan Induced Inflammatory Model and Freund's Adjuvant-Induced Arthritis Model in Rats. Journal of Toxicology 2019 (2019): 1-11.
26. Silva JC, de Oliveira Junior RG, e Silva MG, de Lavor EM, Soares JM, et al. LASSBio-1586, an N-acylhydrazone derivative, attenuates nociceptive behavior and the inflammatory response in mice. PLos One 2018; 13 (7): 1-19.

27. Harris RE, Casto BC, Harris ZM. Cyclooxygenase-2 and the Inflammogenesis of breast cancer. World Journal of Clinical Oncology 2014; 5 (4): 677-692.

28. Owolabi OO, James DB, Sani I, Andongma BT, Fasanya OO, Kure B. Phytochemical analysis, antioxidant and anti-inflammatory potential of Feretia apodanthera root bark extracts. BMC Complementary and $A l$ ternative Medicine 2018; 18 (1): 1-9.

29. Matthew, S., Jain, A. K., James, M., Matthew, C. and Bhowmik, D. Analgesic and anti-inflammatory activity of Kalanchoe pinnata (Lam.) Pers. Journal of Medicinal Plants, 2013 1(2), 24-28.

30. Andrade LN, De Sousa DP. A review on anti-inflammatory activity of monoterpenes. Molecules 2013; 18 (1): 1227-1254.

31. Bayala B, Bassole IH, Gnoula C, Nebie R, Yonli A, Morel L, et al. Chemical composition, antioxidant, anti-inflammatory and anti-proliferative activities of essential oils of plants from Burkina Faso. PLos One 2014; 9 (3): 1-9.

32. Zou L, Zhang Y, Li W, Zhang J, Wang D, Fu J, Wang P. Comparison of chemical profiles, anti-inflammatory activity, and UPLC-Q-TOF/MS-based metabolomics in endotoxic fever rats between synthetic borneol and natural borneol. Molecules 2017; 22 (9): 1-15.

33. Soleimani M, Sheikholeslami MA, Ghafghazi S, Pouriran R, Parvardeh S. Analgesic effect of $\alpha$-terpineol on neuropathic pain induced by chronic constriction injury in rat sciatic nerve: Involvement of spinal microglial cells and inflammatory cytokines. Iranian Journal of Basic Medical Sciences 2019; 22 (12):1445-1451.

34. Aggarwal BB, Yuan W, Li S, Gupta SC. Curcumin-free turmeric exhibits anti-inflammatory and anticancer activities: Identification of novel components of turmeric. Molecular Nutrition \& Food Research 2013; 57(9): 1529-1542.

35. Gbenou JD, Ahounou JF, Akakpo HB, Laleye A, Yayi E, Gbaguidi F, et al. Phytochemical composition of Cymbopogon citratus and Eucalyptus citriodora essential oils and their anti-inflammatory and analgesic properties on Wistar rats. Molecular Biology Reports 2013; 40(2): 1127-1234.

36. Arruda C, Mejía JA, Ribeiro VP, Borges CH, Martins $\mathrm{CH}$, Veneziani RC, et al.Occurrence, chemical composition, biological activities and analytical methods on Copaifera genus-A Review. Biomedicine \& Pharmacotherapy 2019; 109: 1-20.

African Health Sciences, Vol 21 Issue 1, March, 2021 
37. Li R, Yang JJ, Song XZ, Wang YF, Corlett RT, $\mathrm{Xu} \mathrm{YK}$, et al. Chemical Composition and the Cytotoxic, Antimicrobial, and Anti-Inflammatory Activities of the Fruit Peel Essential Oil from Spondias pinnata (Anacardiaceae) in Xishuangbanna, Southwest China. Molecules 2020; 25 (2): 1-13.

38. Vieira AJ, Beserra FP, Souza MC, Totti BM, Rozza AL. Limonene: Aroma of innovation in health and disease. Chemico-Biological Interactions 2018; 283: $97-$ 106.

39. Rufino AT, Ribeiro M, Sousa C, Judas F, Salgueiro L, Cavaleiro C, et al. Evaluation of the anti-inflammatory, anti-catabolic and pro-anabolic effects of
E-caryophyllene, myrcene and limonene in a cell model of osteoarthritis. European Journal of Pharmacology 2015; 750: 141-150.

40. Khodabakhsh P, Shafaroodi H, Asgarpanah J. Analgesic and anti-inflammatory activities of Citrus aurantium L. blossoms essential oil (Neroli): Involvement of the nitric oxide/cyclic-guanosine monophosphate pathway. Journal of Natural Medicines 2015; 69 (3): 324 331.

41. Jin D, Dai K, Xie Z, Chen J. Secondary Metabolites Profiled in Cannabis inflorescences, Leaves, Stem Barks, and Roots for Medicinal Purposes. Scientific Reports 2020; 10 (1): 1-4. 